AperTO - Archivio Istituzionale Open Access dell'Università di Torino

\title{
Economic integration and labour market policy in EMU
}

\section{This is a pre print version of the following article:}

Original Citation:

\section{Availability:}

This version is available http://hdl.handle.net/2318/1512538

since 2015-08-25T10:12:11Z

Publisher:

Edward Elgar Publishing

Terms of use:

Open Access

Anyone can freely access the full text of works made available as "Open Access". Works made available under a Creative Commons license can be used according to the terms and conditions of said license. Use of all other works requires consent of the right holder (author or publisher) if not exempted from copyright protection by the applicable law. 


\title{
Economic Integration and Labour Market Policy in EMU
}

\author{
Giuseppe Bertola (Università di Torino and CEPR)
}

December 2008

For Oesterreichische Nationalbank "The Integration of European Labour Markets" proceedings.

\section{Labour market policy: goals and constraints}

Labour market institutions have an important role in a world where financial markets and public redistribution schemes are imperfect, inaccessible, or ineffective. Minimum wages, collective bargaining, unemployment insurance, and employment protection legislation can target income redistribution across individuals and over time. In doing so, they cannot generally avoid loss of productive efficiency: unemployment insurance and employment protection tend to shift labour into unemployment, and to remove individual mobility incentives to allocate labour where it would be most productive.

Like the serious health problems and other life-shaping events targeted by government policies, job loss can result from the individual's own behaviour, which cannot be readily observed, as well as from objective circumstances which are hard to verify. Hence, private contracts cannot generally protect workers from labour income risk. An insurance contract specifying the circumstances where a worker would be entitled to compensation when fired would be exceedingly complex to write, and essentially impossible to enforce privately. Workers covered by incomplete private insurance contracts would not work as hard, and would be fired so much 
more promptly than uninsured workers as to make insurance either unprofitable for the issuer, or too costly for purchasers.

Governments have obvious enforcement advantages and may exploit better information about individual circumstances and interactions across agents, and for this reason policy interventions in labour markets are widespread and, to some extent, beneficial. Collective instruments, however, need not unambiguously improve welfare. Political decision processes may be shaped by inefficient rent-seeking incentives, and the information problems that prevent financial markets from providing insurance also imply efficiency losses from imperfect government policies. Workers covered by unemployment insurance (UI) schemes do not have strong incentives to avoid job loss and to find new jobs, and employment protection legislation (EPL) that makes it difficult for employers to fire redundant workers slows down labour reallocation towards more productive jobs, thus reducing production and profitability, at the same time as it stabilizes workers' labour income.

For these reasons, lower employment and higher unemployment are unavoidable side effects of policies meant to redistribute income towards workers who cannot easily access those financial markets that, in a perfect world, would make it possible for them to partake of aggregate production, and to stabilize random labour income fluctuations. Different countries choose the stringency and character of policies differently. In some countries, financial markets are relatively well developed, and UI and EPL are implemented at low intensity. Countries equipped with suitable administration schemes prefer to control labour income risk with UI; other countries implement EPL, effectively shifting the burden of labour income smoothing on employers. 
Figure 1 illustrates the impact of labour market policies in a stylized way. If workers faced by a downward-sloping labour demand function only care about the aggregate wage bill, they are collectively better off when the wage is set at a level higher than that which equates supply and demand. The higher wage at the end of the upward-pointing arrow implies lower employment along the labour demand schedule, as indicated by the horizontal arrow in the picture, as well as smaller production: but the incidence of smaller production is not on workers if they earn no other income than wages.

Unlike "representative" individuals, who also consider the producer's surplus between the wage and labour's marginal productivity, workers are better off when taxes and regulations increase the marginal productivity of labour, and the resulting wage bill. This may be achieved by legal or contractual wage minima which imply unemployment (involuntary from the perspective of individual workers, who are prevented from bidding down the wage of employment relationships), as well as by payroll taxes which finance transfers to non-employed individuals, in the form of pension or unemployment or family benefits. All such policies serve similar purposes: while an explicit wage floor prohibits workers from bidding down other workers' wages, alternative income-support sources eliminate the need to bid for employment. Other policies, such as employment protection legislation and unemployment insurance schemes, also aim at redistributing income flows, not only away from other factors and towards labour, but also across workers who enjoy better or worse luck in the labour market, and cannot access private financial and insurance markets so as to offset the implications of labour income fluctuations for their family's welfare. And these policies also trade off such welfare gains off losses of productive efficiency and employment, as they unavoidably slow down reallocation of labour from relatively less to relatively more productive jobs. 


\section{National policies and international economic integration}

International economic integration tends to worsen the employment and unemployment side effects of national policies meant to raise and stabilize labour incomes. Employment is more sensitive to production costs when factors can be substituted and production moved across countries' borders, and prices have stronger effects on product sales in more competitive markets. Economic integration improves employment and production opportunities, making it possible to exploit comparative advantage or scale economies, so as to improve production efficiency. Just because it makes it easier for markets to compare and choose among alternative modes and locations of production, however, economic integration also increases the elasticity of employment to labour costs (see Andersen and Skaksen, 2007, for an explicit model and a fuller formal discussion).

International economic integration allows market participants not only to pursue efficiency more freely, but also to circumvent collective regulation. Thus, economic integration makes it difficult or impossible to enforce policies meant to shape individual choices differently from what would be implied by imperfect market mechanisms(Sinn, 2003). To the extent that labour market rigidities prevent countries from reaping the fruits of economic integration, their effects on employment and productivity should be all the more negative as technical progress and policy reforms dismantle barriers to international trade and factor mobility, and it may be expected that governments should find it desirable to deregulate their countries' labour markets (Bertola, 2006).

This has clear implications for the effects of labour market policies meant to alter labour market outcomes for income distribution purposes. As shown in Figure 2, a flatter labour demand 
relationship implies that a given wedge inserted between labour demand and supply implies sharper employment losses. The smaller wage gains implied by a flatter labour demand worsen the trade-off faced by labour market policy, as it reduces its positive impact on labour income and strengthens its unemployment and inefficiency side effects. If policies are reformed in light of this, then employment may well increase. Reforms are difficult to implement, however, also because many forward-looking decisions are based on their framework, and any deregulation denies some workers protection they thought they could count on. Through this mechanism, economic integration may be associated with worse employment outcomes if policies are not suitably reformed.

As integration tends to foster efficiency of employment, it increases the level as well as the cost sensitivity of labour demand. Hence, wages and employment can both increase even as policy becomes less intrusive (Andersen and Skaksen, 2007). But a higher elasticity of labour demand also implies more volatility of employment and wages in response to product market shocks (Scheve and Slaughter, 2004). This increases the appeal of policies meant to buffer the welfare implications of uninsurable risk (Agell, 2002). Thus, economic integration increases the desirability of labour market regulation (as long as markets remain imperfect) at the same time as it decreases its efficacy. In practice, the balance of these forces may associate economic integration with more or less pervasive institutional interference with labour market mechanisms.

\section{An empirical question, and answers from EMU}

The European countries that joined EMU are characterized by particularly pervasive and possibly inefficient regulation of labour markets, and EMU's peculiarly strong form of economic 
integration also fosters political incentives to improve labour market flexibility: since member countries renounce all independence in monetary and trade policy, and much independence in other policies, political processes that might otherwise preserve the institutional status quo of labour markets can be forced into reform. As "there is no alternative" (TINA), EMU countries should find it desirable to deregulate their labour markets. Monetary union can however foster a "there is no need" rather than a TINA attitude in political-economic interactions: in the absence of crisis danger, and of national monetary policy tools, unions and employers may not set wages so as to ensure a satisfactory employment outcome (Calmfors, 2001).

While aggregate wage and employment flexibility is certainly important in the absence of exchange rate changes, relative wage and employment flexibility is perhaps even more important across the regions, sectors, and occupations of countries where market integration reduces the relevance of country-level shocks and increases that of specific shocks. As other adjustment channels are shut down in a single-currency area, flexibility of labour markets may be a priority from the EMU-wide point of view. But labour market policy making remains essentially national, so actual reform patterns are influenced by coordination problems.

This interrelated set of possible channels of interaction between labour market policies, labour market outcomes, and international economic integration defines an interesting and essentially empirical question. Deeper economic integration in the Euro area may be associated with better or worse employment performances, depending on whether sharper negative employment effects of existing policies, or the resulting tendencies to deregulate labour markets, are the dominant feature of actual country experiences. To flesh out the relevant mechanisms, it interesting not only to see whether employment and unemployment performances are different 
in and out of EMU, but also to see whether the EMU economic integration experience yields evidence of labour market deregulation and of sharper effects of remaining regulation.

In order to characterize these phenomena, it is possible to try and detect differences between countries and periods that are in and out of EMU. Early data did not offer strong evidence in this respect (Duval and Elmeskov, 2006). But research by Bertola (2008b) and Alesina, Ardagna, and Galasso (2008) explores more recent data to see whether Economic Monetary Union was associated with significant deregulation in product and labour markets. The data and methodologies of these papers are similar, and not surprisingly yield consistent results. EMU countries experienced substantial deregulation of their product markets and some deregulation of their labour markets, especially in the 'secondary' segments where workers find temporary employment. Deregulation was not uniform across countries and policy instruments, and it is possible to detect in the data relationships between the speed and character of deregulation, and other relevant variables' paths. Within EMU, for example, product market reforms were more significant in countries that were experiencing loss of competitiveness. Labour tax reductions, while sharper in EMU and statistically related to the trade expansion associated with adoption of the single currency, were also empirically related to country-specific budgetary conditions. And while the generosity of unemployment insurance schemes actually increased in EMU, it was mirrored by a relatively fast decline of the stringency of employment protection provisions.

The tables in this chapter document a subset of such findings, focusing on the association of EMU with differences in labour market outcomes and labour taxes, as detected by regressions on a "dummy" variable that equals zero in non-EU countries and in EU countries that have not 
yet adopted the common currency in the year considered, but equals unity in 1999 and later years for Austria, Belgium, Germany, Spain, Finland, France, Ireland, Italy, Netherlands, Portugal, and in 2001 and later years for Greece. Of course, changes could be more gradual than adoption of the euro, reflecting anticipation effects and adjustment lags. Bertola (2008b) shows that the results are essentially identical to those detected by the EMU dummy coefficient if regressions are specified so as to allow trends in the 1995-2005 to differ across the countries that eventually do and do not adopt the common currency.

To control for permanent country characteristics, the regressions include fixed effects, so that country-specific constants absorb the implications of climate, culture, and other country-specific features that are certainly relevant for employment, unemployment, and policies, but are difficult to measure precisely and unlikely to change over a limited span of years. The regressions also include year effects, to avoid attributing to EMU the effects of concurrent developments, such as the global business cycle and EU enlargement, that presumably affect EMU and other comparable countries in similar ways. Accordingly, the regression coefficient of an EMU dummy picks up the average difference (between countries that do and do not adopt the single currency) of year-specific means of the left-hand side variable. That coefficient is influenced by contemporaneous developments only to the extent that they affect Eurozone countries differently from others, and by the unobserved country features absorbed by fixed effects only to the effect that those features interact with EMU membership in equally unobserved (but relevant) ways.

In Table 1, there is evidence that EMU is associated with lower unemployment and higher employment. Bertola (2008b) also finds that the evidence is stronger in the youth and female 
segments of the labour force. These demographic groups' labour supply and employment outcomes are more sensitive to policy wedges (Bertola, Blau, and Kahn, 2007), but may also reflect cultural trend differences that have little to do with economic integration. For this reason, a more reliable gauge of policy-related developments may be the prime-age male employment rate, which Bertola (2008b) finds to be significantly higher in EMU country-period observations than in a broad comparison group including non-EMU members of the EU and other comparable OECD countries.

Thus, at least part of the raw change in labour market outcomes for the sample of countries that did join EMU appears to be associated with EMU itself, rather than with the identity of the countries or with the influences of common (to the industrialized countries in the sample) factors captured by year effects. There is weak or no evidence in Table 1 of changes in per capita or per-hour production, suggesting that a movement along the labour demand curve was accompanied by an upward shift of labour productivity relative to the control group.

There is similar evidence of an association between EMU and changes in labour market policies. The decline in labour taxation is statistically insignificant in the fifth column of Table 1 , but it is easy to find stronger evidence of regulation with regressions specifications meant to investigate a little deeper the determinants of policy choices. In the next column, controlling for government deficits (Maastricht definition) increases the size and significance of the average labour tax reduction in EMU vis-à-vis the non-EMU portion of the sample: since year and country dummies are included, the significantly negative impact of EMU on labour taxation becomes evident when the relative need to improve government finances is accounted for. 
It is also possible to see whether in the data, as in the theory illustrated by Figure 2, labour market policy has sharper negative implications for employment under conditions of tighter economic integration. Consider, for example, the association between employment rate and tax wedge data. In Figure 3, the overall association between the two is ambiguously sloped: some countries, such as Sweden, are able to sustain both high employment and high taxes, while others, such as Greece, lie low along both dimensions. This presumably reflects specific characteristics of each country's economic and social structure, such as the more or less "encompassing" character of their policymaking and wage bargaining processes. But the figure also shows that many countries experienced large shifts in both of these variables over the sample period, and that typical country-specific trajectories are negatively sloped (in the direction of lower taxes and higher employment).

Do the data support theoretically sensible association of tighter integration with more negative employment effects of labour market policies? Figure 4 offers a simple 'yes' answer: if the data points are split into those that refer to an EMU country and period and those that do not (plotted by $\mathrm{E}$ and 0 symbols, respectively, in the figure), the slope of the relationship between employment and taxation is more negative in the former group. The difference, while statistically significant in the underlying regressions, is not dramatic in the figure, where the slopes of both regressions lines struggle to fit observations both across and within the countries in each group. It is possible to obtain more convincing evidence allowing each country to have its own intercept (the coefficient of country fixed effects, as in Table 1) and running regressions of employment rates on labour taxation and its interaction with economic integration. 
Controlling for country fixed effects, the first column of Table 2 estimates a very significant and large coefficient for labour taxes as an explanatory variables of aggregate employment rates in the EU15 sample. Among the forces driving tax and employment outcomes along tradeoffs such as that illustrated in Figure 1, some - such as increasing openness to Far East trade and technological changes - are common across the entire sample. But others may be specific to EMU members and years. The second column of Table 2 includes the EMU dummy and its interaction with labour tax rates among the explanatory variables, thus allowing the relationship between taxes and employment to differ across the EMU and non-EMU subsamples. Again controlling for country fixed effects, the regressions detect a negative and strongly significant interaction. Bertola (2008b) also finds that there is a negative and significant interaction between labour taxes and trade openness, which in turn is empirically related to adoption of a common currency.

\section{Summary and implications}

The evidence is consistent with the mechanisms outlined in Section 2: monetary union strengthens the negative association between marginal labour tax rates and employment. Tax reductions associated with EMU, while statistically significant, have a modest economic impact in this exercise, confirming that reforms have not been as dramatic as TINA views might have predicted. But the change in slope illustrated in Figure 2 above can be detected in the data, and does have negative implications for employment. There is similar, and sometimes stronger, evidence as regards other policies and outcomes. In the data, EMU membership is associated with somewhat smaller labour tax rates, and with more general labour market deregulation (European Commission, 2007, 2008; Bertola, 2008b). While reforms were nowhere near as 
drastic as "TINA" views might have led one to expect, the resulting higher employment can be viewed as confirmation that, in an integrated economic area, national labour market policies face less favourable tradeoffs: unchanged national policies would have implied employment losses, and deregulation more than offset that tendency in the actual EMU experience. Consistently with this view, remaining tax differences - as might be implied by different budgetary and political conditions - appear to be more strongly and negatively associated with employment in EMU than out of it.

When interpreting the evidence it is important to keep in mind that countries that adopted the euro certainly differ from the others in many relevant respects. They were not forced by an experimenter to join EMU. They chose to do so, and their decision was presumably influenced by their own characteristics as well as by the relationships between observable variables detected in the data. The observed pattern of institutional and outcome dynamics can be a natural consequence of the fact that many of the first wave of Eurozone countries had the most room for unemployment reduction and flexibility-oriented reforms. The data can neither confirm nor deny that countries in the sample that did not but could join (Denmark, the UK, and Sweden) did not want or need to reform, or that countries that did join EMU may have done so also in order to obtain suitable reform incentives. But they can tell us that the intensity and the (good and bad) effects of country-level policy interference with labour market outcomes are correlated with EMU membership.

Just like uncoordinated macroeconomic policies, fixed exchange rate, and free capital mobility were incoherent with each other before Economic and Monetary Union, so free mobility of goods and/or factors, local decision-making powers in the labor-market and social protection 
area, and social inclusion coexist uneasily (Bertola, 2007): privileging two of the three aspects necessarily implies forsaking the third. Independent National policymaking authority in an integrated, barrier-free markets reduces the incisiveness of policies. The evidence reviewed in this chapter indicates that EMU has indeed been associated with at least some deregulatory tendency in the labour market.

Bertola $(2008 \mathrm{a}, \mathrm{b})$ also documents an association of these phenomena with higher disposable income inequality, also driven by lower social spending. Financial market development can control the welfare effects of income inequality and instability, by allowing all individuals to partake both of wages and other forms of income and to smooth the implications of labour income instability by borrowing and lending. EMU has been associated with robust financial development, especially as regards firm financing (Jappelli and Pagano, 2008). In 2008, however, financial turmoil has not spared EMU countries. The resulting loss of confidence in the ability of markets to package and control risk effectively brings labour market policies back to the fore of political debates. To the extent that the effects of labour market institutions are (or are perceived to be) desirable, membership in a monetary union requires different policy approaches, based on harmonized regulation and modernization of insurance-oriented policies and of industrial relations. 


\section{References}

Agell, Jonas (2002) "On the Determinants of Labour Market Institutions: Rent Seeking vs. Social Insurance" German Economic Review 3:2 107-135.

Alesina, Alberto, Silvia Ardagna, and Vincenzo Galasso (2008) "The euro and structural reforms" NBER Working Paper 14479.

Andersen, Torben M. and Jan Rose Skaksen (2007) "Labour Demand, Wage Mark-ups, and Product Market Integration" Journal of Economics 92:2 pp.103-135.

Bertola, Giuseppe (2006) "Social and Labour Market Policies in a Growing EU" Swedish Economic Policy Review 13:1 189-232.

Bertola, Giuseppe (2007) "Welfare Policy Integration Inconsistencies" in Helge Berger and Thomas Moutos (eds) Designing the New European Union, Amsterdam: Elsevier, 91-120.

Bertola, Giuseppe (2008a) "Economic Integration, Growth, Distribution: Does the euro make a difference?" in Lars Jonung and Jarmo Kontulainen (eds.), "Growth and income distribution in an integrated Europe: Does EMU make a difference?" Economic Papers 325, European Economy.

Bertola, Giuseppe (2008b) "Labour Markets in EMU: What has changed and what needs to change," European Economy - Economic Papers 338, European Commission.

Calmfors, Lars (2001) "Wages and Wage-Bargaining Institutions in the EMU - A Survey of the Issues" Empirica 28: 325-351, 2001.

Duval, Romain and Jörgen Elmeskov (2006) "The Effects of EMU on Structural Reforms in Labour and Product Markets" ECB Working Paper No. 596. 
European Commission (2007) "Labour market reforms in the euro area" Quarterly Report on the Euro Area (DG Economics and Finance) IV/2007, 29-33.

European Commission (2008), "Recent labour market reforms in the euro area: characteristics and estimated impact" Quarterly Report on the Euro Area (DG Economics and Finance) $1 / 2008,18-23$.

Jappelli, Tullio, and Marco Pagano (2008) "Financial Market Integration under EMU" CEPR Discussion Paper DP 7091.

Scheve, Kenneth and Matthew J. Slaughter (2004): "Economic Insecurity and the Globalization of Production" American Journal of Political Science, 48(4), 662-674.

Sinn, Hans-Werner (2003) The New Systems Competition, Oxford: Basil Blackwell. 


\begin{tabular}{r|c|c|c|c|c|c}
\hline & $\begin{array}{c}\text { Unemploy- } \\
\text { ment }\end{array}$ & Employment & $\begin{array}{c}\text { GDP per } \\
\text { capita }\end{array}$ & $\begin{array}{c}\text { Labour } \\
\text { productivity }\end{array}$ & Labour Tax & Labour tax \\
\hline EMU & -0.8328 & 1.7308 & -0.0299 & 1.9127 & -0.2589 & -2.3557 \\
\hline $\begin{array}{r}\text { Govt. } \\
\text { Budget }\end{array}$ & -0.94 & 2.13 & -0.05 & 0.63 & -0.35 & -5.44 \\
\hline$t$ & & & & & & 0.1344 \\
\hline $\mathrm{N}$ & 154 & 154 & 154 & 154 & 140 & 1.30 \\
\hline
\end{tabular}

TABLE 1: Regressions on EMU dummy (equal to unity in 1999-2005 for Austria, Belgium, Germany, Spain, Finland, France, Ireland, Italy, Netherlands, Portugal). Year dummies and country fixed effects are included (not shown), robust $t$ statistics are shown below the coefficients. Sample: EU15, 1995-2005.

\section{Data definition and sources:}

Unemployment, age 15 and over, \% of labour force. Source: Eurostat.

Employment, age 15 and over, \% of population. Source: Eurostat.

GDP per capita at 1995 prices, thousands of euro. Source: Eurostat.

Labour productivity per hour worked, PPS gdp, EU15=100. Source: Eurostat.

Labour tax: total wedge in \%, single workers at $100 \%$ of average earnings, no child. Source: OECD.

Govt.Budget: General government surplus (deficit if negative), Maastricht criteria definition, \% GDP. Source: Eurostat. 


\begin{tabular}{r|c|c}
\hline & $\begin{array}{c}\text { Employment } \\
\text { rate }\end{array}$ & $\begin{array}{c}\text { Employment } \\
\text { rate }\end{array}$ \\
\hline Labour Tax & -0.6777 & -0.3470 \\
\hline EMU & -9.36 & -4.63 \\
\hline$t$ & & 6.8981 \\
\hline Labour & & 4.27 \\
\hline Tax*EMU & & -0.1035 \\
\hline$t$ & & -2.89 \\
\hline $\mathrm{N}$ & 140 & 140 \\
\hline
\end{tabular}

TABLE 2: Regressions of total employment rate on labour tax and its interactions with an EMU dummy (equal to unity in 1999-2005 for Austria, Belgium, Germany, Spain, Finland, France, Ireland, Italy, Netherlands, Portugal, in 2002-05 for Greece). Country effects are included (not shown), robust $t$ statistics are shown below the coefficients.

Definition and sources: see note to Table 1. 


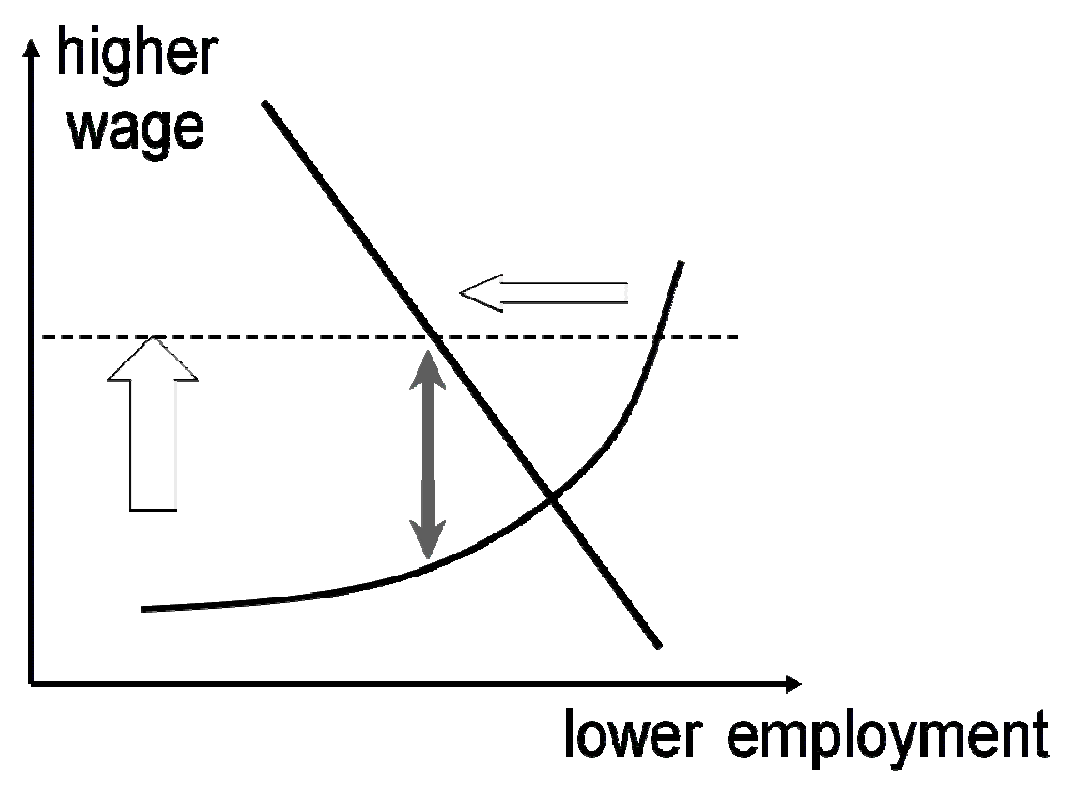

Figure 1: The effect of minimum wages or labour taxes that finance subsidies to workers. 


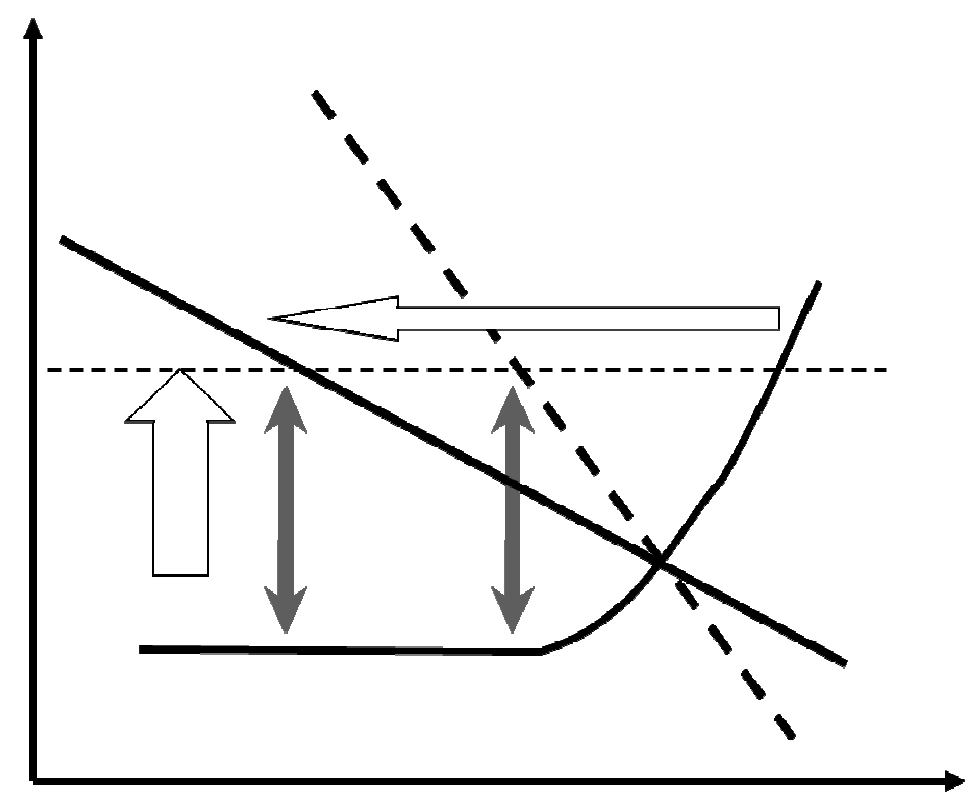

Figure 2: The implications of stronger cost sensitivity of labour demand for the employment effects of labour market policies. 


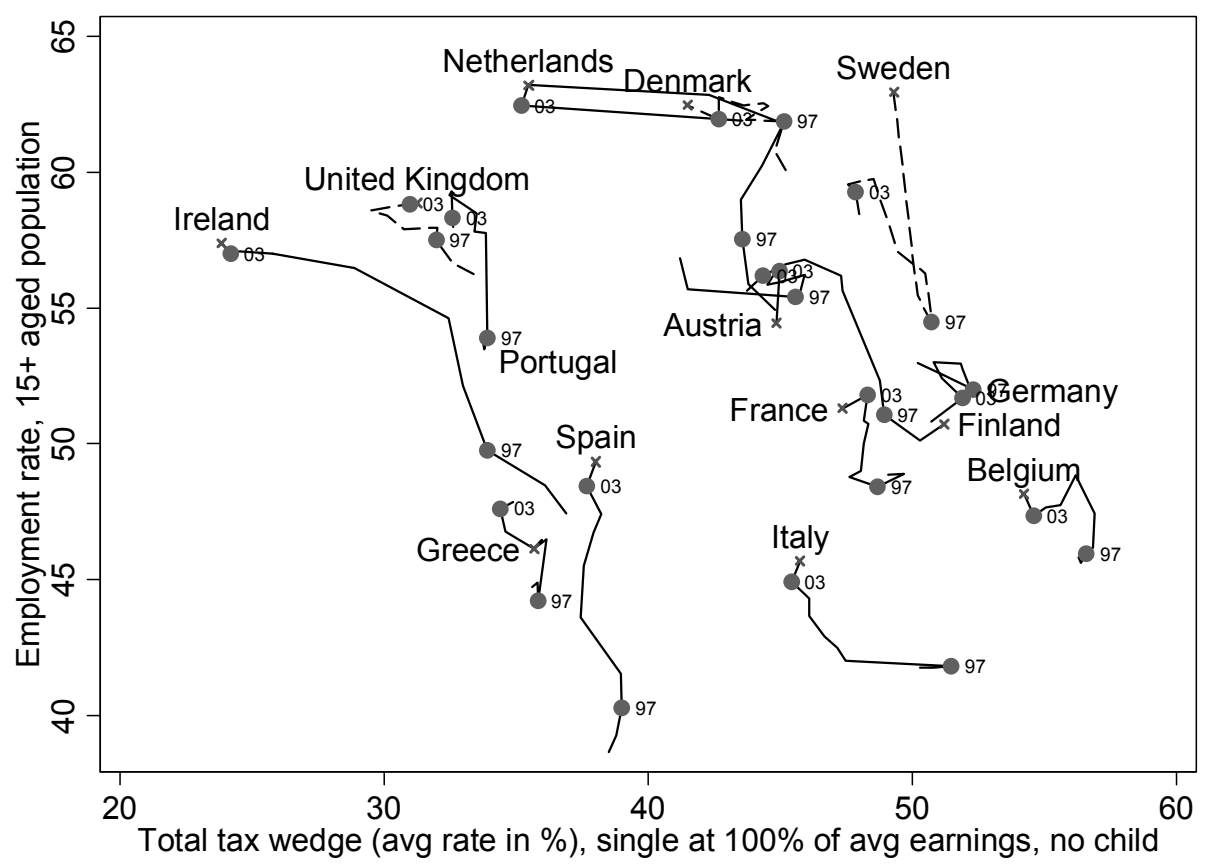

Figure 3: Employment and labour tax rates in the EU15, 1995-2005. Definition and source: see note to Table 1. 


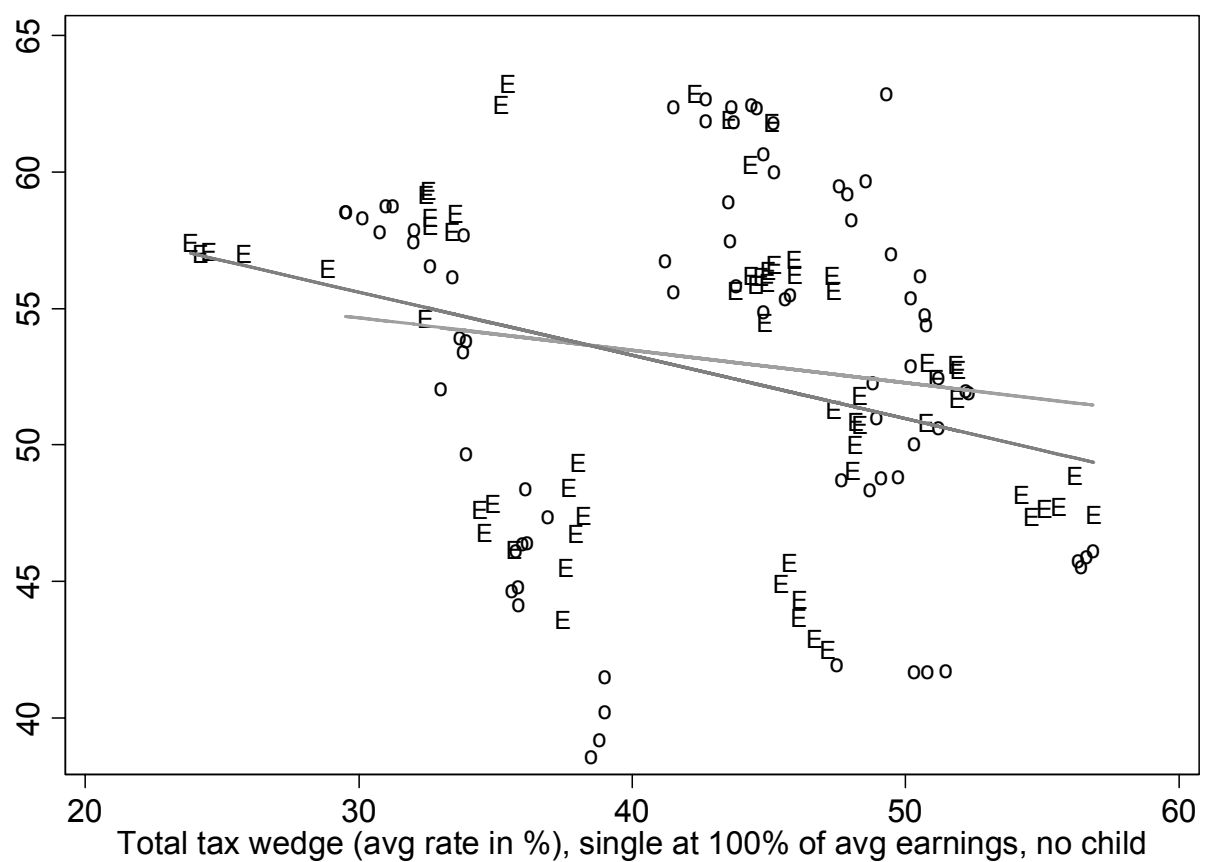

Figure 4: Same data as in Figure 3, and regression lines with different slopes and intercepts for EMU (marked by "E") and non-EMU (marked as "o") observations. The steeper line is the one estimated on the EMU sample, where differences in taxation (across countries and over time) are on average associated with larger differences in employment rates. 